\title{
Audiência de custódia: a concretização da utopia
}

\author{
Custody hearing: the realization of utopia
}

\author{
Nereu José Giacomolli* \\ Caíque Ribeiro Galícia ${ }^{* *}$
}

\section{Resumo}

\begin{abstract}
A superação da mera normatividade doméstica no âmbito criminal avança na perspectiva da efetivação dos compromissos assumidos pelo Brasil no cenário internacional ao internalizar o Pacto Internacional de Direitos Civis e Políticos e a Convenção Americana de Direitos Humanos. Nesse aspecto, o presente artigo aborda alguns aspectos da audiência de custódia como concretização de direitos humanos do sujeito que tem sua liberdade tolhida por agentes estatais. Para tanto, será feita uma análise geral conceitual que envolve esse instituto, utilizando as propostas normativas que deram início a essa discussão no contexto brasileiro, assim como uma leitura sistemática em relação à efetividade da garantia do preso a ser apresentado à autoridade judiciária logo após a sua prisão desde a Convenção Americana de Direitos Humanos (1969). Vale ressaltar a importância do tema no contexto latino-americano e, em especial, brasileiro, marcado por rompimentos democráticos e emprego de violência e tortura por parte de alguns agentes públicos. Objetiva-se apresentar uma noção geral sobre o tema, além de alguns delineamentos sobre aspectos relacionados à concreção de direitos fundamentais como resultado da construção de alterações que vem sendo implantadas no ordenamento jurídico brasileiro. De fato, a legislação brasileira há de ser conformada com os diplomas internacionais ratificados pelo Brasil, sendo que todo ser humano detido possui o direito de ser conduzido à presença da autoridade judicial competente, ser ouvido pessoalmente e verificada a legalidade da prisão - direito e audiência.
\end{abstract}

Palavras-chave: Pacto de São José da Costa Rica. Processo penal. Direito de ser ouvido. Audiência de custódia.

\section{Abstract}

The overcoming of the mere domestic normativity in the criminal context advances in connection with the fulfillment of commitments internationally assumed by Brazil, to internalize the International Pact on Civil and Political Rights and the American Convention on Human Rights. The brazilian law is to be conformed to the international instruments ratified by Brazil and considered in light of the decisions of international Courts. Every human being detained has the right to be led to the presence of the competent judicial authority, to be heard and verified the legality of detention - right and audience. The custody hearing, as meaning, constitutes a guarantee of effectiveness of fundamental rights in the world of criminal procedure.

Keywords: San Jose Of Costa Rica Pact. Criminal procedure. Right to be heard. Custody hearing.

\section{Introdução}

A cena é clássica: o sujeito veste um macacão laranja e é conduzido pelo oficial através do suntuoso tribunal até a presença daquele que se encontra atrás de um grande móvel de madeira. Então, após a apresentação do caso narrado pelo meirinho, há explicações, um pequeno debate, e logo ecoa a voz do magistrado seguida do som aterrorizante do martelo da Justiça. A ilustração acima não trata do julgamento final de um caso criminal, porquanto é a encenação do primeiro contato que o sujeito suspeito pelo

Doutor pela Universidad Complutense de Madrid (Espanha), com estudos de pós-doutorado na Universitá degli Studi di Torino (Itália). Professor no mestrado e doutorado em Ciências Criminais na PUCRS, consultor jurídico e advogado. Porto Alegre - RS- Brasil. E-mail: nereu@giacomolli. com.

Doutorando e mestre em Ciências Criminais pela PUCRS, professor e advogado. Porto Alegre - RS- Brasil. E-mail: caiquerg@hotmail.com. 
cometimento de um crime possui, tão logo é detido, tendo como consequência as tão propagadas fianças (bail) ou a liberdade, com o consequente desenvolvimento da trama cinematográfica.

Apesar de nos parecer tão próxima, a cena não retrata a realidade brasileira. Todavia, a grande indústria cinematográfica norte-americana já nos familiarizou com aquilo que tem sido recentemente o foco da atenção de muitos processualistas penais brasileiros: a audiência de custódia. Assim, segue em trâmite, desde 2011, o Projeto de Lei do Senado n. 554, de autoria do senador Antônio Carlos Valadares, propondo a reforma do art. 306 do CPP, compelindo a apresentação do sujeito detido em flagrante à autoridade judicial como medida de adequação aos tratados internacionais, em especial à Convenção Americana de Direitos Humanos. Ora, parece mesmo que "a vida imita a arte muito mais do que a arte imita a vida". ${ }^{1}$

Nesse contexto, pretende-se analisar a audiência de custódia no cenário brasileiro desde uma compreensão voltada para um processo penal democrático, ${ }^{2}$ fundado especialmente no sistema internacional de proteção dos direitos humanos, ${ }^{3}$ com possibilidade de diálogo entre as diversas fontes doutrinárias e jurisprudenciais (internormatividade e interjurisdicionalidade ${ }^{4}$ ), mas também na dinâmica de institutos processuais concretos em constante aperfeiçoamento e remodelagem, ${ }^{5} \mathrm{com}$ os olhares voltados à redução dos espaços de ilegalidade e do abuso do poder.

Desta forma, cumpre informar de pronto que, metodologicamente, ao tratar de um tema ainda não completamente implementado no sistema processual, passo necessário é a delimitação conceitual do instituto processual, com a abordagem das definições básicas a ele atinentes, permitindo a fixação de standards comuns, quando só a partir de então será possível trazer ao presente estudo algumas reflexões críticas sobre o tema.

O presente trabalho floresce em terreno permeado por dúvidas sobre os conceitos elementares da audiência de custódia e sua extensão, ao mesmo tempo em que diversas ações promovidas pelo Conselho Nacional de Justiça, como a Carta de Teresina ${ }^{6}$ e a Carta de Recife ${ }^{7}$ já ganham espaço e força, acompanhados pelo desenrolar de resoluções ${ }^{8}$ emitidas - emergencialmente - por alguns Tribunais de Justiça estaduais. Mais recentemente, o próprio Supremo Tribunal Federal já se posicionou acerca do tema, tanto na ADI 5.240/SP quanto na ADPF 347/DF. Nessa linha, resta esclarecer que o intuito do presente trabalho não é o de fazer uma análise criminológica ou de política criminal relacionada ao tema, que tem sido a vertente adotada pelos - poucos - escritos acerca do tema. Afinal, naturalmente, a implementação

Frase atribuída ao dramaturgo e poeta Oscar Wilde (1854-1900).

Conforme André Maya (2014, p. 1-2), "o ideal democrático que serviu de paradigma à Constituição vigente e a elevação da dignidade da pessoa humana a fundamento da República Federativa do Brasil impõem seja o Processo Penal entendido, hoje, não mais como apenas um meio necessário à incidência da potestade punitiva do Estado, mas também - e principalmente - como uma forma de tutela dos direitos fundamentais previstos tanto na Carta constitucional, quanto nos tratados internacionais de direitos humanos, como é o caso do Pacto de San José da Costa Rica, do qual o Brasil é parte signatária".

3 Scarance acentua que "na evolução do relacionamento indivíduo-Estado, houve necessidade de normas que garantissem os direitos fundamentais do ser humano contra o forte poder estatal intervencionista. Para isso, os países inseriram em suas Constituições regras de cunho garantista, que impõem ao Estado e à própria sociedade o respeito aos direitos individuais, tendo o Brasil, segundo José Afonso da Silva, sido o primeiro a introduzir em seu texto normas desse teor. Além disso, principalmente após as guerras mundiais, os países firmaram declarações conjuntas, plenas de normas garantidoras, visando justamente a que seus signatários assumissem o compromisso de, em seus territórios, respeitarem os direitos básicos do indivíduo" (FERNANDES, 2007, p. 17).

4 Na lição de Giacomolli (2015, p. 17) "a adequação das regras do processo penal, portanto, ultrapassa a mera adequação constitucional e adere a normatividade internacional, em perspectiva evolutiva das necessidades e possibilidades de realização e, sobretudo, de interdependência, em suma, na realização do devido processo, na perspectiva de um direito inserido na proteção humanitária internacional”.

5 Scarance Fernandes (2007, p. 19) sustenta que "as alterações políticas no tempo e a diversidade de ideologias em uma mesma época fazem com que haja diferentes tratamentos aos institutos processuais na evolução histórica e nos vários países. Em virtude disso, afirma-se que os conceitos dos institutos fundamentais do direito processual não são definitivos, mas relativos. Dependem, essencialmente, da predominância que se dê ao indivíduo em confronto com o Estado, ou, ao contrário, ao Estado em face do indivíduo".

6 Trata-se de Carta elaborada durante o $68^{\circ}$ Encontro do Colégio dos Corregedores de Justiça do Brasil (ENCOGE), ocorrido nos dias 25,26 e 27 de março de 2015 em Teresina/PI, contendo, entre outras deliberações, apoio em relação à realização de "audiências de custódia como política pública de controle do ingresso de presos no sistema carcerário".

7 Refere-se à deliberação ocorrida no Encontro Nacional do Colégio de Presidentes de Tribunais de Justiça do Brasil, onde enfatiza "a implantação do Sistema de Audiências de Custódia, como 'instrumentos céleres e eficazes para a solução de conflitos, defesa dos direitos fundamentais e garantia da cidadania”.

8 Podemos citar o Provimento Conjunto n. 03/2015 do TJSP, o Provimento n. 21/2014, do TJMA, a Resolução n. $13 / 2015$ do TJES e a Resolução n. 796/2015, do TJMG. 
das audiências de custódia está diretamente relacionada à prisão e ao especial impacto nos índices de encarceramento (inclusive, estes são os marcos justificadores da implementação do instituto).

De fato, a situação desumana do sistema carcerário brasileiro ${ }^{9}$ é uma chaga endêmica do nosso sistema, devendo sempre se fazer presente a reflexão no sentido de uma humanização do cárcere na sua dupla vertente: decreto de prisão como ultima ratio (GIACOMOLLI, 2015, p. 40) e condições dignas de higiene, alimentação e segurança dentro dos presídios.

O objeto do presente artigo relaciona-se com a primeira vertente, por ser a que recebe o impacto dos institutos processuais penais na law in action. Todavia, como ficou bem demonstrada após a reforma

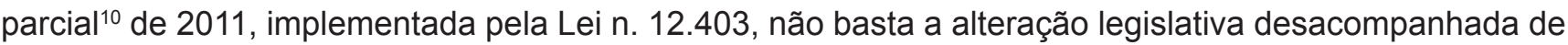
uma mudança de comportamento dos atores processuais no mesmo sentido da norma. Essa é apenas uma das estratégias.

Outras medidas se fazem necessárias à efetivação da garantia ao preso de ser apresentado e ouvido pela autoridade judiciária competente. Dentre elas, destacamos a necessidade de implementação de políticas institucionais, com gestão de prioridades e necessidades, bem como a conscientização de todas as esferas do poder (Legislativo, Judiciário e Executivo), da funcionalidade do sistema criminal, com o afastamento da compreensão de que a criminalidade se resolve somente com Direito Penal e o Direito Processual Penal (funcionalidade espúria). Ademais, faz-se mister diminuir a hipertrofia da racionalidade técnico-instrumental na perspectiva do alcance de uma dimensão ética solidária e político-participativa.

A este respeito, o relatório produzido em 2014 por um grupo de trabalho acerca das prisões arbitrárias, ${ }^{11}$ ligado ao Office of the High Commissioner for Human Rights - ONU - apontou que, "apesar de aspectos positivos das reformas legais no sistema de justiça criminal, na prática, o acesso à justiça para as pessoas detidas possui severas deficiências em vários aspectos". (REPORT OF THE WORKING GROUP ON ARBITRARY DETENTION, 2013).

A partir de tais considerações, o presente artigo tratará, além de alguns aspectos relacionados à previsão normativa internacional, também das bases conceituais fundamentais da audiência de custódia em comparação com a reforma parcial do CPP em 2011, passando pela apresentação do panorama atual brasileiro sobre a matéria. Destacar-se-á as atuais resoluções que já disciplinam, em âmbito estadual, a matéria, além do PLS 554/2011, como tem sido a orientação do Supremo Tribunal Federal sobre o assunto (ADI 5.240/SP e ADPF 347/DF), e, ao final, apresentam-se reflexões propositivas à operacionalização do instituto no caso brasileiro desde a constatação da "vida como ela é". ${ }^{12}$

\section{Fundamentos normativos: para além da mera legalidade interna}

O debate acerca da audiência de custódia surge no Brasil após a evidente não aderência, especialmente por parte dos atores processuais, ${ }^{13}$ das regras contidas na reforma implementada pela

9 Após o último Diagnóstico de pessoas presas no Brasil, realizado pelo CNJ por meio do Departamento de Monitoramento e Fiscalização do Sistema Carcerário e do Sistema de Execução de Medidas Socioeducativas - DMF, publicado em junho de 2014 , o Brasil conta com o total de 711.463 presos (considerando a população carcerária somada aos presos domiciliares), sendo que $32 \%$ são presos provisórios, resultando em um déficit de vagas total de 358.373 presos (BRASIL. CNJ, 2014).

10 Para Geraldo Prado e Antonio Melchior (2011), "Falar em reformas parciais em um Processo Penal que implora por uma mudança estrutural exige cuidado. A promulgação de leis esparsas acarreta a perda de um referencial ideológico consistente, permitindo que a modificação legislativa escape da lógica sistêmica e enfraqueça a proteção das garantias, concebidas e preordenadas constitucionalmente à tutela dos direitos fundamentais".

11 O relatório Report of the Working Group on Arbitrary Detention, realizado oficialmente entre os dias 18 e 28 de março de 2013 a convite do governo brasileiro, visitaram diversos presídios e tiveram amplo acesso aos presos, inclusive realizando entrevistas (ONU, 2013).

12 "A vida como ela é..." se refere a obra de Nelson Rodrigues que diariamente era publicado no periódico Última Hora, retratando histórias de amor, paixão e morte com bastante aderência à realidade do cotidiano vivido por todos, mas nem sempre exposto na literatura.

13 Fauzi Hassan Choukr (2002, p. 132) ainda acentua que "a situação brasileira apresenta uma delicadeza particular quando se pensa na cultura emergencial, característica comum aos países em processo de (re)democratização, onde os valores que lhes são próprios mal são estabelecidos no pacto de civilidade e acabam por ser desmoralizados na prática dos operadores do direito - e na prática social, de forma geral - que assim conferem uma vivência apenas forma ao cânones culturais da normalidade". 
Lei n. 12.403/2011, cujo objetivo, de inverter o sistema anteriormente em voga - fundado na manutenção da prisão como regra ${ }^{14}$-, não foi alcançado. ${ }^{15}$ Pode-se perceber que, mesmo após a reforma, na maioria dos casos levados ao magistrado - como exigência imediata na regra do art. 306, CPP -, há apenas uma homologação pro forma da prisão, ${ }^{16}$ e em outros casos, diversos pedidos de prisão preventiva baseados apenas em conceitos abstratos, como garantia da "ordem pública", ${ }^{17}$ sem consistência fática em relação ao caso penal, perpetuam a cultura anterior de verdadeira pena antecipada (GLOECKNER, 2015, p. 333) e colaboram com a inflação carcerária.

Nota-se que a reforma de 2011 possui, dentre tantos, três pontos que merecem atenção pela sua importância sistemática em relação à prisão e que nos fornecem a ponte entre a reforma em questão e a lógica da implementação da audiência de custódia, quais sejam, (i) a fixação do prazo de 24 horas para a comunicação de qualquer tipo de prisão ao juiz e, se for o caso, também à defensoria pública (art. 306, $\left.\S 1^{\circ}, \mathrm{CPP}\right)$, (ii) a conversão da prisão em flagrante em prisão preventiva como última medida processual (GIACOMOLLI, 2015, p. 41) (art. 282, §6 e art. 310, inc. I, II e III e parágrafo único, todos do CPP) e, especialmente, (iii) a possibilidade do exercício do contraditório na aplicação de medidas cautelares ${ }^{18}$ (art. 282, §3, CPP).

Soma-se a tal situação o fato de que, em regra, desde 2008, o interrogatório do réu, primeira oportunidade em que o sujeito detido teria contato direto com o magistrado, é o último ato da instrução (art. 400, CPP) a ser realizado em audiência antes das alegações finais e julgamento. Na hipótese de prisão em flagrante convertida em preventiva, na atual sistemática, o réu praticamente só terá oportunidade de ser realmente ouvido pelo magistrado apenas no último momento antes de seu julgamento, e após toda a produção probatória.

O contato do acusado com o juiz é o momento adequado ao exercício da defesa pessoal, elemento integrante da ampla defesa, de modo a possibilitar que o detido possa contraditar pessoalmente a necessidade e a legalidade da prisão. $O$ espaço público ${ }^{19}$ da audiência é o locus oficial à efetivação das garantias processuais e à limitação do poder, o qual se constitui em importante elemento da decisão de deter e lavrar o flagrante, bem como de decisão de homologar e decretar a prisão preventiva.

Este cenário está marcado por um completo afastamento do réu em relação não só ao magistrado, mas também de toda a ritualística processual, caracterizando um sistema não humanitário que privilegia a obscuridade do rito, onde o sujeito é tratado como mero objeto da investigação, da persecutio criminis, do processo, em afronta aos Tratados Internacionais e à Constituição Federal, como parte verdadeiramente

14 Segundo Aury Lopes (2015, p. 51) "a sociedade acostumada com a velocidade da virtualidade não quer esperar pelo processo, daí a paixão pelas prisões cautelares e a visibilidade de uma imediata punição".

15 Ainda em relação ao Relatório da ONU, consta que, "apesar da emenda feita no Código de Processo Penal em 2011 permitir medidas alternativas à prisão, o Grupo de Trabalho observou que não houve uma redução substancial no uso da detenção desde a introdução da emenda", acrescentando que "apesar das medidas positivas observadas, o Grupo chama atenção ao Governo acerca de medidas que devem ser direcionadas efetivamente para garantir a proteção contra a privação arbitrária da liberdade", referindo-se, neste ponto, especialmente aos padrões internacionais de proteção dos direitos humanos, citando, inclusive o Pacto Internacional dos Direitos Civis e Políticos (art. $\left.9^{\circ}\right)$. (Tradução dos autores). (ONU, 2014).

16 Diga-se, a esse respeito, especialmente os casos envolvendo a Lei n. 11.343/06, onde no contexto da "Guerra às Drogas", há, praticamente, uma automática conversação em prisão preventiva com base no perigo abstrato e no risco que pode gerar, verdadeiro direito penal do autor, baseado em futurologismos. Ademais, como o usuário de drogas não pode mais ser recolhido ao cárcere, os flagrantes passaram a ser por tráfico, na medida da ampla discricionariedade na diferenciação entre traficante e usuário (local do flagrante, antecedentes, etc.).

17 É precisa a lição de Fauzi (2002, p. 148-149) quando afirma que "esse conceito fluído acaba abarcando as idéias (sic) como as de presunção de periculosidade e o emprego da prisão processual como juízo de hipótese de realização de novo delito. [...] Aqui a ordem pública fruto podre da tutela penal semeada pelas considerações da teoria law and order se faz sentir de maneira intensa. Tolhe-se a liberdade pelo emprego esotérico da premonição".

18 A respeito desse - tímido - contraditório contido no $\S 3^{\circ}$ do art. 282, Aury Lopes (2012, p. 785) já prenunciava: "Mas intimação para quê? Para uma audiência? Apresentar resposta escrita? O dispositivo não diz. Pensamos que o ideal seria o juiz, à luz do pedido de adoção de alguma medida cautelar, intimar o imputado para uma audiência, onde sob a égide da oralidade se efetivaria o contraditório e o direito de defesa, na medida em que o acusador sustentaria os motivos de seu pedido e o réu, de outro lado, argumentaria sobre a falta de necessidade da medida (seja por fragilidade do fumus commissi delicti,seja do periculum libertatis)".

19 A esse respeito, Ferrajoli (2014, p. 567-572) aponta que tanto a oralidade quanto a publicidade são elementos garantidores do próprio sistema e do devido processo penal, consideradas garantias das garantias e que são as bases, pois negam a escrita e o segredo, do sistema acusatório. 
de um conto kafkaniano. ${ }^{20} \mathrm{Na}$ situação desenhada pelo Código de Processo Penal brasileiro, o detido em flagrante é conduzido à delegacia de polícia onde é lavrado o auto de prisão em flagrante. Em seguida, é conduzido ao cárcere, e os papéis do flagrante são remetidos ao juiz, com conhecimento do Ministério Público. O juiz então decide acerca da prisão sem ver nem ouvir o flagrado; decide com base na versão incriminatória constante nos papéis.

O conteúdo destes possui mais valor que o ser humano, pois o flagrado é afastado da mesa processual, não é considerado, embora seja o principal sujeito e aquele que suporta concretamente os efeitos. Com isso, sacramenta-se uma prisão sem contraditório, sem defesa e sem aderência aos diplomas internacionais protetivos dos direitos humanos. A perspectiva oficial da legalidade e necessidade da prisão integrará o processo e possui fortes probabilidades de aderência judicial durante todo o iter procedimental. O preso somente será apresentado ao juiz no final do processo, quando está prestes a ser julgado, legitimando-se a barbárie pelo processo penal, sem reconhecimento do Outro como ser humano.

Fácil perceber a coisificação daquele que sofre a ameaça da espada da Justiça, na contramão do paradigma ético ${ }^{21}$ que clama um processo penal humanitário, com um acusado como sujeito de direitos, estruturado na valorização da dignidade da pessoa humana como fundamento do Estado de Direito e, ao mesmo tempo, oponível à universalidade (eficácia vertical e horizontal dos direitos fundamentais). $\mathrm{O}$ paradigma totalitário de processo penal, forjado nas décadas de trinta e quarenta do século passado, enraizou-se nos sujeitos processuais e na sociedade contemporânea, de modo que há um clamor pelo incremento de penas, pelo recolhimento ao cárcere e pela desnecessidade de garantias a quem comete um ilícito. Nessa perspectiva situa-se a resistência à efetivação da audiência de custódia no Brasil.

Há necessidade de superação da definição de norma, de conceito, de instituto ou mesmo de resposta jurídica na perspectiva da linguagem legislada domesticamente pelo Estado, no contexto de uma sociedade contemporânea complexa, orientada a partir do fenômeno da globalização e funcionando em redes de cooperação, ${ }^{22}$ que se faz mister o reconhecimento - e efetividade - dos diplomas internacionais relacionados aos direitos humanos (bloco de constitucionalidade). Cria-se uma rede de proteção que ultrapassa o âmbito doméstico e chega até os standards fixados nos sistemas internacionais de proteção dos direitos humanos, como o africano (Carta Africana dos Direitos Humanos e dos Povos), o europeu (Convenção Europeia de Direitos Humanos) e o interamericano (Convenção Americana de Direitos Humanos ou Pacto de São José da Costa Rica).

No que diz respeito ao sistema regional interamericano, o qual, naturalmente, o Brasil faz parte, é composto essencialmente pela Carta da Organização dos Estados Americanos (1948), pela Declaração Americana dos Direitos e Deveres do Homem (1948), pela Convenção Americana sobre Direitos Humanos (1969) e pelo Protocolo Adicional à Convenção Americana em Matéria de Direitos Econômicos, Sociais e Culturais (1988) (MAZZUOLI, 2011, p. 19). Todavia, vale apontar também a relevância a presente abordagem do Pacto Internacional sobre Direitos Civis e Políticos (1966), internalizado no ordenamento jurídico brasileiro por meio do Decreto 592/1992.

\footnotetext{
20 Digna de registro a passagem: "o princípio segundo o qual tomo decisões é: a culpa é sempre indubitável. [...] Faz uma hora o capitão se dirigiu a mim, tomei nota das suas declarações e em seguida lavrei a sentença. Depois determinei que pusessem o homem na corrente. Tudo isso foi muito simples. Se eu tivesse primeiro intimado e depois interrogado o homem, só teria surgido confusão. Ele teria mentido, e se eu o tivesse desmentido, teria substituído essas mentiras por outras e assim por diante. Mas agora eu o agarrei e não o largo mais" (KAFKA, 1998, p. 37-38), complementada pela precisa lição de Ricardo Timm (2011, p. 73) que aponta a alienação do condenado diante da sentença, afirmando que "num papel extremamente precioso está escrito algo absolutamente claro para quem conhece e absolutamente ilegível para quem permanece fora da lógica da razão labiríntica".

21 Conforme Nereu Giacomolli (2008, p. 14), "o paradigma ético de processo penal valoriza o ser humano, o outro, reflexo do eu, todos seres imperfeitos, com origem e fim certos. O Estado e sua ritualística, ao estimular a delação do outro ou as confissões contra os corréus, com promessas de impunidade ou de benefícios penológicos, reconhece a sua incompetência em desvendar os crimes, corrompe e descaracteriza o ser humano".

22 A nova ordem mundial representa um sistema de governança global que institucionaliza a cooperação e possui conflitos tais que todas as nações e pessoas pode atingir maior paz e prosperidade, alcançando um padrão mínimo de dignidade humana (tradução dos autores) (SLAUGHTER, 2005, p. 15).
} 
Pode-se afirmar que, atualmente, tanto a Convenção Americana de Direitos Humanos - CADH como o Pacto Internacional sobre Direitos Civis e Políticos - PIDCP, correspondem aos dois mais importantes instrumentos internacionais relacionados à proteção dos direitos humanos no Brasil. Ambos passaram a integrar o ordenamento jurídico no ano de 1992, por meio de decretos, sendo por muito tempo discutida a natureza jurídica de tais tratados, especialmente após a Emenda Constitucional $n^{\circ} 45 / 2004$, a qual acrescentou o $\S 3^{\circ}$ ao art. $5^{\circ}$ da Constituição Federal, com a previsão de quórum qualificado para a internalização de tratados formalmente como emendas constitucionais. A discussão chegou ao STF através do RExt. 466.343, em um caso que versava sobre a prisão civil de depositário infiel, quando então o STF fixou o entendimento de que os tratados internacionais de direitos humanos ratificados antes da EC 45/2004 teriam status normativo supralegal, paralisando as normas que com ele viessem a conflitar.

Vale destacar que tal solução jurídica se deu somente em razão, no caso brasileiro, da autorização constitucional contida em cláusula pétrea da prisão do depositário infiel (art. $5^{\circ}$, LXVII, CF), de maneira que a interpretação mais adequada e em conformidade com a atual valorização dos direitos humanos é a de que, nos casos em que não há conflito direto com a Constituição Federal, os tratados internacionais que versam sobre direitos humanos integram o bloco de constitucionalidade; materialmente constitucionais, portanto, por força do art. $5^{\circ}, \S \S 1^{\circ}$ e $2^{\circ}$, da $C F .23$

Superado esse ponto, especificamente em relação ao tema tratado neste trabalho, o art. $7^{\circ}, 5$, $\mathrm{CADH}^{24}$ e o art. $9^{\circ}, 3, \mathrm{PIDCP},{ }^{25}$ enunciam com pequena variação na redação que "qualquer pessoa, quando oficialmente detida, deve ser encaminhada, sem demora, a uma autoridade judiciária". Tal previsão é o fundamento normativo para o que se denomina de audiência de custódia, cujo objetivo, nos termos dos tratados internacionais, é possibilitar que a pessoa detida tenha um contato direto com o magistrado imediatamente após a restrição da sua liberdade de locomoção.

\section{Em busca de standards conceituais}

Inobstante as considerações feitas em relação ao status jurídico de norma materialmente constitucional, mesmo sendo ambos tratados formalmente internalizados no ordenamento jurídico brasileiro desde 1992, até o presente momento não há qualquer norma processual - em âmbito federal regulamentadora do direito de ser ouvido, sem demora, por autoridade judicial.

Ocorre que, ao ratificar os instrumentos, o Brasil assumiu a obrigação (shall secure) convencionalinternacional e, no caso específico da $\mathrm{CADH},{ }^{26}$ está submetido a sua jurisdição ${ }^{27}$ em uma dupla dimensão, ou seja, além do dever de (i) respeitar os direitos e liberdades contidos no Pacto, conforme art. $1^{\circ}, \mathrm{CADH}$, o país deve também (ii) adotar as medidas legislativas necessárias para tornar efetivos tais direitos e liberdades (art. $\left.2^{\circ}, \mathrm{CADH}\right)$.

23 Na clara lição de Flavia Piovesan (2007, p. 55) "a Constituição assume expressamente o conteúdo constitucional dos direitos constantes dos tratados internacionais dos quais o Brasil é parte. Ainda que esses direitos não sejam enunciados sob a forma de normas constitucionais, mas sob a forma de tratados internacionais, a Carta lhes confere o valor jurídico de norma constitucional, já que preenchem e complementam o catálogo de direitos fundamentais previsto pelo Texto Constitucional".

24 "Toda pessoa presa, detida ou retida deve ser conduzida, sem demora, à presença de um juiz ou outra autoridade autorizada por lei a exercer funções judiciais e tem o direito de ser julgada em prazo razoável ou de ser posta em liberdade, sem prejuízo de que prossiga o processo. Sua liberdade pode ser condicionada a garantias que assegurem o seu comparecimento em juízo" (grifo dos autores).

25 "Qualquer pessoa presa ou encarcerada em virtude de infração penal deverá ser conduzida, sem demora, à presença do juiz ou de outra autoridade habilitada por lei a exercer funções judiciais e terá o direito de ser julgada em prazo razoável ou de ser posta em liberdade. A prisão preventiva de pessoas que aguardam julgamento não deverá constituir a regra geral, mas a soltura poderá estar condicionada a garantias que assegurem o comparecimento da pessoa em questão à audiência, a todos os atos do processo e, se necessário for, para a execução da sentença" (grifo dos autores).

26 Embora o PIDCP possua normas no mesmo sentido (art. $1^{\circ}, 3$ e art. $2^{\circ}, 1$ e 2, ambos do PIDCP), o sistema regional de proteção dos direitos humanos $(\mathrm{CADH})$ está mais estruturado, inclusive com a possibilidade de sanções junto aos dois principais órgãos (CIDH e CortelDH), razão pela qual o trabalho dará enfoque a esse tratado.

27 Mazzuoli (2011, p. 24-34) esclarece que a proteção - e monitoramento - dos direitos contidos na CADH possui dois principais mecanismos: a Comissão e a Corte Interamericana de Direitos Humanos, em que a atribuição da Comissão está relacionada com o exame das comunicações acerca de possíveis violações de direitos humanos constantes na CADH, enquanto a Corte possui competência consultiva e contenciosa (jurisdicional) de julgamento de casos concretos de possíveis violações. 
Desta forma, o Brasil se mantém omisso nessas duas vertentes, embora a reforma de 2011 tenha sido um primeiro esforço no sentido de adequar o ordenamento jurídico - no que diz respeito às prisões aos tratados internacionais. Isso porque, conforme já exposto, a reforma legislativa de 2011 (Lei n.12.403) alterou parte do CPP incluindo três pontos bastante relevantes, ${ }^{28}$ os quais agora merecem atenção especial, pois representam a criação da base estrutural daquilo que hoje se revela possível alcançar por meio das audiências de custódia.

Neste diapasão, a norma contida nos dois tratados internacionais (CADH e PIDCP) é bastante similar, e claramente indica a exigência de se colocar o acusado pessoalmente em frente a um magistrado quando for detido pela prática de uma infração penal. Não se pode olvidar da comparação com os antecedentes históricos do próprio instituto do habeas corpus, que se tratava da possiblidade concreta de levar o acusado perante a autoridade judicial para verificação da prática de abusos (ilegalidades) contra o detido (LOPES JR., 2012, p. 1321-1325).

Destaca-se que a audiência de custódia vem acompanhada por uma concepção humanitária do processo penal, em que o acusado - sujeito de direitos - merece o tratamento digno, ${ }^{29}$ garantindo-lhe os direitos fundamentais insculpidos na Constituição Federal e nos Tratados internacionais desde o primeiro momento da restrição da liberdade. Para tanto, faz-se mister uma nova metodologia hermenêutica (também analítica e linguística), valorativa, comprometida de forma ético-política, dos sujeitos do processo e voltada ao plano internacional de proteção dos direitos humanos, por isso há que se falar em processo penal constitucional, convencional e humanitário, ou seja, do devido processo penal.

O referido comparecimento pessoal deve ocorrer perante uma autoridade judiciária, ou, nos termos da CADH, a "autoridade autorizada por lei a exercer funções judiciais", de maneira que, de acordo com o entendimento da CIDH e também em conformidade com o ordenamento jurídico brasileiro, a única hipótese juridicamente possível é de apresentação do detido a um magistrado legalmente investido no cargo e com função jurisdicional (PAIVA, 2015, p. 47 e ss). Não se vislumbra, portanto, qualquer possibilidade de ser suprida a exigência da CADH na hipótese de apresentação à autoridade policial ${ }^{10}$ ou membro do Ministério Público. O exercício da jurisdição penal é função exclusiva de juízes e Tribunais competentes e prédeterminados como regra constitucional e convencional. Está na hora de a idiotia jurídica ser desnudada e trazida ao lume, sob pena de continuarmos na senda de um sistema criminal medievalesco.

Ora, a medida em questão pretende justamente ser uma ferramenta para, além de garantir a proteção do indivíduo contra abusos e torturas, rotineiramente cometidos no Brasil, também serve ao controle jurisdicional da legalidade e convencionalidade da prisão e a sua manutenção, como já deveria acontecer desde a reforma de 2011, conforme determina o art. 310, do CPP.

A partir da norma convencional também é possível compreender a dimensão do direito contido no art. 7.5 da $\mathrm{CADH}$, abrangendo não apenas o nacional do Estado-parte, mas absolutamente toda pessoa que esteja em território onde a Convenção tenha sido ratificada. Desta forma, um estrangeiro oriundo de

$281^{\circ}$ ) Comunicação da prisão, em 24 horas, ao juiz e, se for o caso, defensoria pública; $2^{\circ}$ ) Possibilidade de contraditório nas medidas cautelares; e $3^{\circ}$ ) Imposição de prisão como última medida a ser imposta;

29 Para Dworkin (2012, p. 211), quando trata de princípio éticos, se desdobram em (i) princípio do respeito próprio, em que cada um deve levar sua própria vida a sério, aceitando o que é importante para uma realização bem sucedida e não uma oportunidade perdida; e (ii) princípio da autenticidade, significando que cada um tem a responsabilidade especial e pessoal de viver por meio de um estilo coerente e por si aprovado. $\mathrm{E}$ prossegue o autor afirmando que ambos princípios "oferecem uma conceção (sic) da dignidade humana; a dignidade requer respeito próprio e autenticidade. A distinção entre os dois princípios pode parecer artificial; cada qual podia ter o nome do outro. Só se pode pensar que é importante escolher valores que regem a forma como vivemos se pensarmos que é importante que a nossa vida tenha valor. De outro modo, por que razão devemos recorrer aos valores para nos identificarmos?".

30 Nesse ponto, totalmente na contramão do que vem sendo aceito pela doutrina e jurisprudência, mas, especialmente, em completo desalinhamento com a compreensão de um processo penal orientado pela Constituição e pelos Tratados Internacionais, o julgamento, pelo TJSP, do HC n. 2016152-70.2015.8.26.0000, de relatoria do Des. Guilherme de Souza Nucci, julgado em 12/05/2015, considerou que "conforme dispõe o art. $7^{\circ}, 5$, da Convenção Americana de Direitos Humanos, toda pessoa presa, detida ou retida deve ser conduzida, sem demora, à presença de um juiz ou outra autoridade autorizada por lei a exercer funções judiciais. No cenário jurídico brasileiro, embora o Delegado de Polícia não integre o Poder Judiciário, é certo que a Lei atribui a esta autoridade a função de receber e ratificar a ordem de prisão em flagrante". SÃO PAULO. Tribunal de Justiça de São Paulo. HC n. 2016152-70.2015.8.26.0000, de relatoria do Des. Guilherme de Souza Nucci, julgado em 12/05/2015. Assim, inobstante os equívocos processuais contidos, não há como interpretar a norma da CADH como compatível a apresentação do preso junto ao Delegado de Polícia. 
país não pertencente ao sistema interamericano de proteção aos direitos humanos, uma vez detido em local a ela subordinado, mesmo assim por ela está protegido e deveria ser-Ihe garantido a possibilidade de se fazer pessoalmente presente frente a um magistrado, face to face.

Outro desdobramento da regra em questão é que ela abarca toda situação caracterizada por restrição - oficial - da liberdade pessoal, razão pela qual a opção de se colocar os termos detida ou retida deve ser interpretada no sentido de abranger qualquer forma de detenção, independentemente da sua natureza jurídica, quer seja cautelar, pré-cautelar, quer outra medida de retenção. ${ }^{31} \mathrm{~A}$ esse respeito, é importante compreender que a prisão em flagrante - apesar do seu tenebroso histórico no Brasil - não representa a instrumentalidade das medidas cautelares. Afinal, não possui função acauteladora do processo, nem de instrumentalizar a incidência da potestade punitiva estatal, menos ainda de antecipar a tutela penal.

Assim, a nosso entender é plenamente cabível a realização da audiência de custódia para toda e qualquer detenção realizada por órgão estatal (flagrante, preventiva ou temporária), momento no qual o magistrado deverá analisar, na concretude fática vital, se ainda estão latentes os motivos autorizadores da detenção; a adequação da concessão de liberdade; a imposição de medida cautelar ou, em último caso, a decretação (ou manutenção) da prisão preventiva.

Em relação ao prazo da realização da medida, a CADH estabeleceu apenas que a medida deve se dar sem demora. Com isso, relega a atribuição de regulamentar o prazo para cada Estado-parte, com base nessa referência abstrata. O entendimento da CIDH não é homogêneo (PAIVA, 2015, p. 47 e ss.), razão pela qual se exige nesse ponto maior atenção interpretativa, e em consonância com a reserva do possível na realidade da práxis brasileira, único caminho possível para estruturar um projeto viável.

O termo "sem demora" tem sido interpretado pela CIDH de forma bastante variável. Contudo, seguindo o comando normativo é possível chegar a um entendimento que seja viável na realidade brasileira ao mesmo tempo em que satisfaça a exigência convencional. Assim, após a reforma de 2011 nas medidas cautelares, especialmente o art. 306, $\S 1^{\circ}$, CPP, houve o estabelecimento de uma solução provável quando faz a relação entre a imediaticidade (termo contido no caput do art. 306, CPP) e a fixação do prazo de 24 horas $\left(\S 1^{\circ}\right.$ do art. 306, CPP) para que a prisão seja comunicada ao juiz. Pode-se ponderar a estreita ligação entre a previsão contida no dispositivo em questão e a necessidade de apresentação do detido ao magistrado, embora tal fato se restrinja, atualmente, ao aspecto formal de mera comunicação, viciando sistematicamente também a análise posterior, quando a grande maioria dos magistrados apenas homologa o flagrante e, se tiver pedido de decretação da prisão preventiva, da mesma forma, quase que automaticamente, já a decreta, com raríssimas exceções.

Desta feita, não há óbice à manutenção do mesmo prazo (24 horas) para que seja o detido levado perante o juiz, posto que, ao finalizar as formalidades relacionadas à prisão em flagrante (oitiva dos envolvidos, etc.), a autoridade policial, por já ter o dever de encaminhar os documentos para o magistrado, no mesmo ato disponibiliza o acusado, situação similar para os demais casos envolvendo prisão temporária e preventiva.

Essa é a interpretação possível e factível na perspectiva de outorgar efetividade ao dispositivo convencional e em conformidade com a realidade forense brasileira. A escusa utilitária de falta de estrutura e aparelhamento da administração da Justiça não encontra validade ou legitimidade na relegação secundária aos direitos fundamentais. O capital do conhecimento e das experiências há de ser compartilhado. Finda as considerações centrais e a fixação de padrão mínimo de compreensão acerca dos conceitos básicos extraídos dos dois tratados internacionais, resta adentrar na análise das normas infralegais já existentes no Brasil: o PLS 554/2011 e o posicionamento do STF na ADI 5.240/SP e na ADPF 347/DF. 


\section{0 caso brasileiro: reflexos normativos e jurisprudenciais}

No panorama atual, não há nenhuma norma (emanada do legislativo) regulamentando o direito convencionalmente previsto, mantendo-se omisso o Poder Legislativo brasileiro, embora esteja em trâmite o PLS 554/2011, de autoria do senador Antônio Carlos Valadares, que atualmente encontra-se em análise perante a Comissão de Constituição, Justiça e Cidadania.

É omissa também a jurisdicionalidade brasileira ao não dar interpretação conforme da normatividade ordinária do Código de Processo Penal à normatividade convencional (Pacto de São José da Costa Rica) e considerar ilegal a prisão quando não apresentado o detido, imediatamente, a uma autoridade com jurisdição criminal pré-determinada.

Por outro lado, um giro na direção da efetividade das garantias e do cumprimento da CADH e do PIDCP foi dado pelo Supremo Tribunal Federal, ao determinar que os juízes e tribunais realizem, no prazo de 90 dias, as audiências de custódia, com apresentação do preso em 24 horas (ADPF 347MC/DF, rel. Min. Marco Aurélio, início do julgamento em 27.8.2015).

O projeto original teve por objetivo a alteração da redação atual do art. $306, \S 1^{\circ}$, do CPP para constar que "no prazo máximo de vinte e quatro horas depois da prisão, o preso deverá ser conduzido à presença do juiz competente, ocasião em que deverá ser apresentado o auto de prisão em flagrante, acompanhado de todas as oitivas colhidas e, caso o autuado não informe o nome de seu advogado, cópia integral para a Defensoria Pública" (grifo dos autores). Embora bastante importante a previsão, pode-se questionar sob o aspecto técnico alguns termos utilizados em relação, especialmente à previsão apenas da prisão em flagrante.

Tal situação não foi corrigida quando, após a análise perante a Comissão de Assuntos Econômicos, o PLS 554/2011 obteve parecer favorável à aprovação com as emendas substitutivas (aprovadas na Comissão de Direitos Humanos e Legislação Participativa) apresentadas pelo senador João Capiberibe, para constar que

no prazo máximo de vinte e quatro horas após a prisão em flagrante, o preso será conduzido à presença do juiz para ser ouvido, com vistas às medidas previstas no art. 310 e para que se verifique se estão sendo respeitados seus direitos fundamentais, devendo a autoridade judicial tomar as medidas cabíveis para preservá-los e para apurar eventual violação. (Grifo dos autores).

O avanço na emenda substitutiva foi a reestruturação de todo o art. 306 para inclusão de parágrafos destinados a regulamentar aspectos importantes em relação à audiência de custódia, como o contraditório oral ${ }^{32}$ tanto para decretação da prisão preventiva como para a imposição de medidas $\left(\S 2^{\circ}\right)$. Outro detalhe importante foi a vedação expressa da utilização dos termos da audiência de custódia como meio de prova, restringindo a audiência para tratar da medida cautelar em seu aspecto legal $\left(\S 3^{\circ}\right)$ exclusivamente. Por fim, o $\S 5^{\circ}$ do art. 306 do CPP estabelecerá - caso aprovado o PLS 554/2011 - direito de o réu ser acompanhado por defensor (constituído ou público), circunstância que naturalmente já estaria implícita a partir da leitura constitucional e convencional do processo penal.

Desta forma, a proposta de emenda ao projeto original torna-se mais adequada em relação à previsão convencional, embora ainda maculada por prever a realização da audiência apenas nos casos de prisão em flagrante (excluindo do rol a prisão preventiva e a temporária), conforme já exposto. Todavia, as alterações contidas na emenda resguardam de maneira mais efetiva os direitos fundamentais do acusado, tornando-se grande avanço na construção de um processo penal humanitário. Na sistemática do projeto, a própria audiência será o espaço destinado para manifestação do MP quanto ao possível pedido de decretação de medida cautelar diversa ou de prisão preventiva, e submetido ao contraditório (defesa técnica), o magistrado decidirá, pautando pela celeridade e oralidade do ato.

Segundo Ferrajoli (2014, p. 570), o valor da oralidade, a partir dos ensinamentos de Chiovenda e Calamandrei, reside especialmente na imediação e concentração do juízo, também aspirações ratificadas pontualmente pelo legislador brasileiro nas reformas legislativas parciais. 
Por outro lado, efeito imediato do vácuo normativo fez com que os Tribunais de Justiça estaduais, atendendo a demandas de órgãos de classe, mais especialmente do $\mathrm{CNJ}$, começassem uma verdadeira corrida para regulamentar a matéria em âmbito estadual por meio de provimentos e resoluções internos, gerando uma heterogenia de normas reguladoras da matéria. Inclusive, em relação ao Provimento Conjunto $n^{\circ} 3 / 2015$, a Associação dos Delegados de Polícia do Brasil - ADEPOL impetrou ação direta de inconstitucionalidade (ADIN 5.240/SP ${ }^{33}$ ) sustentando, entre outros fatores, a usurpação de competência privativa em razão da matéria processual (art. 22, I, CF) e também a divisão funcional de poder, pois os delegados de polícia estão subordinados ao Poder Executivo.

O provimento cuja constitucionalidade estava sendo questionada, foi publicado no Diário da Justiça (ano VIII, edição 1.814) no dia 27 de janeiro de 2015, e determina, dando "cumprimento ao disposto no artigo $7^{\circ}$, item 5, da Convenção Americana sobre Direitos Humanos (Pacto de San Jose da Costa Rica), a apresentação de pessoa detida em flagrante delito, até 24 horas após a sua prisão, para participar de audiência de custódia", ${ }^{34}$ além de regular outros pontos relativos aos procedimentos para a realização da audiência. O Procurador-Geral da República emitiu parecer considerando que o Provimento dá efetividade a um direito que, já internalizado no ordenamento jurídico brasileiro, possui, ao menos, uma eficácia potencial, sendo descabido o argumento apresentado pela ADEPOL, além de preliminarmente o Provimento ser norma secundária, razão pela qual a ADIN não é o instrumento jurídico adequado para tanto; ${ }^{35}$ e o STF, conhecendo em parte da ação, a julgou improcedente, com decisão publicada em 31/08/2015.

Contudo, vale expor a tendência do posicionamento do STF no julgamento de liminar na ADPF 347/DF, em que há arguição sobre as violações aos direitos humanos no sistema carcerário brasileiro, questionando a omissão dos poderes públicos no tratamento da questão prisional. Em sua decisão, o Min. Marco Aurélio defere a medida liminar para, entre outros pontos, impor aos magistrados a fundamentação expressa sobre não adotar as medidas alternativas à prisão, e também para que seja realizada audiência de custódia em 24 horas após a prisão, como antes referido.

Acrescenta-se, neste panorama, as ações proativas do CNJ favoráveis à realização das audiências, incentivando a regulamentação pelos Tribunais de normas no âmbito de cada Estado com intuito de dar efetividade à CADH. Assim, os regulamentos internos, já em vigor, possuem em seus eixos centrais certa convergência com os pontos mais importantes acerca da matéria e, atualmente, as normas regulamentadoras são: (i) Provimento Conjunto n 3/2015, de (TJSP), (ii) Resolução n 796/2015, de 24 de junho de 2015 (TJMG), (iii) Resolução n 13/2015, de 9 de abril de 2015 (TJES), já que o TJMA revogou o Provimento 21/2014 e o TJMT até o momento não publicou a resolução regulamentadora.

Assim, as normas do TJSP, TJMG e do TJES, preveem o mesmo prazo de 24 horas para a apresentação do preso para a realização da audiência, que deverá se dar, necessariamente, com a presença de um defensor (constituído ou público) e do Ministério Público. Destaca-se, neste cenário, a valorização da oralidade e a consequente celeridade e concentração, dela decorrentes. Afinal, a audiência versa exclusivamente para a análise da necessidade da medida cautelar e do controle de práticas abusivas.

As normas também apresentam similitude quanto à vedação da utilização do termo de audiência de custódia como meio de prova para instrução processual do caso penal, previsão alinhada com o devido processo penal, com os tratados internacionais e a própria Constituição Federal. Todavia, nos instrumentos normativos dos tribunais aqui comentados, há previsão de dispensa de realização da audiência "quando circunstâncias pessoais, descritas pela autoridade policial" ${ }^{36}$ justificarem. Ora, tal exceção, contendo expressões cuja interpretação é demasiada aberta é exatamente o que esvazia o propósito da realização da audiência.

\footnotetext{
33 De relatoria do Min. Luiz Fux, trata-se de questionamento da constitucionalidade do Provimento Conjunto n. 3 do TJSP, impetrado pela Associação dos Delegados de Polícia do Brasil - ADEPOL-BRASIL em 12/02/2015. (BRASIL. STJ, 2015).

34 SÃO PAULO. Tribunal de Justiça de São Paulo. Documento. Disponível em: <http://www.tjsp.jus.br/Handlers/FileFetch.ashx?id_arquivo=65062>. Acesso em: 28 jul. 2015.

35 BRASIL. Supremo Tribunal Federal. Documento. Disponível em: <http://redir.stf.jus.br/estfvisualizadorpub/jsp/consultarprocessoeletronico/ ConsultarProcessoEletronico.jsf?seqobjetoincidente=4711319>. Acesso em: 28 jul. 2015.

36 Art. $3^{\circ}, \S 2^{\circ}$, do Provimento Conjunto n. 3/2015, TJSP e art. $2^{\circ}$, §3º, da Resolução 796/2015, TJMG.
} 
As "circunstâncias pessoais" que poderiam impedir seriam apenas aquelas relacionadas com o alto grau de risco de resgate do detido, o que poderia ser sanado com o deslocamento do juiz até o presídio, ou até mesmo com o uso de vídeo conferência, conforme havia sido previsto no Provimento 21/2014 do TJMA. De fato, descabida a dispensa da audiência apenas fundada em um problema sistêmico de infraestrutura. A máquina burocrática há de se alinhar aos parâmetros da proteção convencional, de efetivação dos direitos fundamentais, sob pena de continuarem as violações às garantias processuais.

\section{Conclusão}

A efetivação dos direitos fundamentais depende do nível de compreensão da normatividade constitucional e convencional. Desde que o Brasil ratificou a Convenção Americana de Direitos Humanos, obrigou-se a adaptar a sua legislação interna ao regramento da $\mathrm{CADH}$. As reformas parciais do Código de Processo Penal de 2008 e as de 2011, que introduziram medidas cautelares alternativas ao recolhimento ao cárcere, não tiveram o condão de instituir a audiência de custódia. Não bastasse isso, juízes e Tribunais poderiam dar ao art. 306 do CPP uma interpretação convencional conforme, considerando ilegal a prisão quando não apresentado o preso a uma autoridade judicial imediatamente. O preso há de ser apresentado a uma autoridade imbuída do poder jurisdicional, e não a outra. Ademais, não há distinção entre preso em flagrante e preso preventivamente, ou pela modalidade temporária, pois toda pessoa detida há de ser vista e ouvida pela autoridade judicial competente (direito de audiência) "sem demora".

A estrutura do Código de Processo Penal brasileiro é da década de quarenta. Apesar das modificações parciais que ocorreram ao longo do tempo, as regras não foram adaptadas à Constituição Federal e nem aos diplomas internacionais. Os sujeitos oficiais seguem a estrutura ordinária desvinculada da contemporaneidade e arraigada na ideologia italiana da década de trinta (Rocco) e das décadas de trinta e quarenta do Brasil (ditadura Vargas). O produto disso é o encarceramento massivo, a prisão como antecipação da tutela material penal e a crença na recuperação pelo encarceramento. A instituição e obrigatoriedade da audiência de custódia pretende interferir na modificação dessa realidade.

\section{Referências}

BRASIL. Supremo Tribunal Federal. Processo eletrônico. Disponível em:

$<$ http://redir.stf.jus.br/estfvisualizadorpub/jsp/consultarprocessoeletronico/ConsultarProcessoEletronico.js f?seqobjetoincidente=4711319>. Acesso em: 28 jul. 2015.

CHOUKR, Fauzi Hassan. Processo penal de emergência. Rio de Janeiro: Lumen Juris, 2002.

DWORKIN, Ronald. Justiça para ouriços. Coimbra: Almedina, 2012.

FERRAJOLI, Luigi. Direito e razão. São Paulo: Revista dos Tribunais, 2014.

FERNANDES, Antonio Scarance. Processo penal constitucional. 5. ed. São Paulo: Revista dos Tribunais, 2007.

GIACOMOLLI, Nereu J. O devido processo penal: abordagem conforme o Pacto de São José da Costa Rica e a Constituição Federal. 2. ed. São Paulo: Atlas, 2015.

GIACOMOLLI, Nereu J. Prisão, liberdade e as cautelares alternativas ao cárcere. São Paulo: Marcial Pons, 2013.

GIACOMOLLI, Nereu J. Reformas (?) do processo penal: considerações críticas. Rio de Janeiro: Lumen Juris, 2008.

GLOECKNER, Ricardo J. Risco e processo penal: uma análise a partir dos direitos fundamentais do acusado. São Paulo: JusPodium, 2015.

KAFKA, Franz. Na colônia penal. São Paulo: Companhia das letras, 1998. 
LOPES JR., Aury. Direito processual penal. 9. ed. São Paulo: Saraiva, 2012.

LOPES JR., Aury. Fundamentos do processo penal: introdução crítica. São Paulo: Saraiva, 2015. MAYA, André Machado. Imparcialidade e processo penal: da prevenção da competência ao juiz de garantias. São Paulo: Atlas, 2014.

MAZZUOLI, Valerio de O. Os sistemas regionais de proteção dos direitos humanos: uma análise comparativa dos sistemas interamericano, europeu e africano. São Paulo: Atlas, 2011.

PAIVA, Caio. Audiência de custódia. Florianópolis: Empório do Direito, 2015.

PIOVESAN, Flávia. Direitos humanos e o direito constitucional internacional. 8. ed. São Paulo: Saraiva, 2007.

PRADO, Geraldo; MELCHIOR, Antonio Pedro. Breve análise crítica da lei n. 12.403, de 2011, que modifica o regime das cautelares pessoais no processo penal brasileiro. Boletim do IBCCRIM, São Paulo: IBCCRIM, ano 18, n. 223, p. 10-11, jun. 2011.

SÃO PAULO. Tribunal de Justiça de São Paulo. Documento. Disponível em: <http://www.tjsp.jus.br/ Handlers/FileFetch.ashx?id_arquivo=65062>. Acesso em: 28 jul. 2015.

SLAUGHTER, Anne-Marie. A new world order. Princeton: Princeton University Press, 2004.

SOUZA, Ricardo Timm de. Kafka: a justiça, o veredicto e a colônia penal. Um ensaio. São Paulo: Perspectiva, 2011.

Recebido em: 05/10/2015

Aprovado em: 25/08/2016 